\title{
ROCK PORE STRUCTURE AS MAIN REASON OF ROCK DETERIORATION
}

\author{
MARTIN ONDRÁŠIK, MILOSLAV KOPECKÝ
}

Department of Geotechnics, SvF STU Bratislava, Radlinského 11, 81368 Bratislava, Slovakia, e-mail: martin.ondrasik@stuba.sk, miloslav.kopecky@stuba.sk

\begin{abstract}
Crashed or dimensional rocks have been used as natural construction material, decoration stone or as material for artistic sculptures. Especially old historical towns not only in Slovakia have had experiences with use of stones for construction purposes for centuries. The whole buildings were made from dimensional stone, like sandstone, limestone or rhyolite. Pavements were made especially from basalt, andesite, rhyolite or granite. Also the most common modern construction material - concrete includes large amounts of crashed rock, especially limestone, dolostone and andesite.

However, rock as any other material if exposed to exogenous processes starts to deteriorate. Especially mechanical weathering can be very intensive if rock with unsuitable rock properties is used. For long it had been believed that repeated freezing and thawing in relation to high absorption is the main reason of the rock deterioration. In Slovakia for many years the high water absorption was set as exclusion criterion for use of rocks and stones in building industry. Only after 1989 the absorption was accepted as merely informational rock property and not exclusion. The reason of the change was not the understanding of the relationship between the porosity and rock deterioration, but more or less good experiences with some high porous rocks used in constructions exposed to severe weather conditions and proving a lack of relationship between rock freeze-thaw resistivity and water absorption.

Results of the recent worldwide research suggest that understanding a resistivity of rocks against deterioration is hidden not in the absorption but in the structure of rock pores in relation to thermodynamic properties of pore water and tensile strength of rocks and rock minerals.

Also this article presents some results of research on rock deterioration and pore structure performed on 88 rock samples. The results divide the rocks tested into two groups - group $\mathrm{N}$ in which the pore water does not freeze even when the temperature decreases to $-20^{\circ} \mathrm{C}$, and the second group $\mathrm{F}$ in which the pore water freezes. It has been found that the rocks from group $\mathrm{N}$ contain critical portion of adsorbed water in pores which prevents freezing of the pore water. The presence of adsorbed water enables thermodynamic processes related to osmosis which are dominantly responsible for deterioration of rocks from group N. A high correlation $(R=0.81)$ between content of adsorbed water and freeze-thaw loss was proved and can be used as durability estimator of rocks from group $\mathrm{N}$. The rock deterioration of group $\mathrm{F}$ is caused not only by osmosis, but also by some other processes and influences, such as hydraulic pressure, permeability, grain size, rock and mineral tensile strength, degree of saturation, etc., and the deterioration cannot be predicted yet without the freeze-thaw test. Since the contents of absorbed water and ratio between adsorbed and bulk water (of which the absorbed water consists) is controlled by the porosity and pore structure, it can be concluded that the deterioration of some rocks is strongly related to rock pore structure.
\end{abstract}

Key words: mechanical weathering, rock deterioration, adsorbed water, adsorbed water freezing, rock porosity, freeze-thaw loss

\section{INTRODUCTION}

It is well known that rocks exposed at the Earth's surface to the climatic conditions start to deteriorate due to mechanical breakdown and chemical decay (mechanical and chemical weathering). Similar destiny is designated also to products made from natural rock material like crashed rock for construction of roads or production of concrete, dimensional stone for construction and decoration of buildings. In old historical towns, not only in Slovakia, the whole buildings were made from dimensional stone prepared from sandstone, limestone or rhyolite. Pavements were made especially from basalt, andesite, rhyolite or granite.

The driving forces of the rock deterioration are the climatic conditions, defined by temperature and humidity. If the rock is exposed to non changing temperature or humidity it stays in the same shape and condition for ever. Also in dry climatic conditions where only temperature is being changed the rocks are durable. However, as soon as water is introduced into rock pores the process of rock deterioration is accelerated. The water has become agent of rock deterioration by its chemical, physical and thermophysical properties as well as it becomes medium for transpor- 
tation of chemical agents which are causing the chemical weathering.

Movement of water is restricted to interconnected pores (effective porosity) and it depends upon the pore structure how freely the pore water can move, at what temperature it freezes, what its thermodynamic properties are, whether the pore water behaves as hydraulic or osmotic fluid, whether the water in pores becomes bulk or adsorbed, what the maximum degree of saturation is, etc.

Although there is a wide variety of influences and dependences between water and rock pore structure, for long time it had been believed that repeated freezing and thawing related to high absorption is the main reason of the rock deterioration. Theories of hydraulic pressure [28], [29] and other were developed for explanation of the rock deterioration after freezing. Because of general acceptance of relationship between high water absorption by rocks and low rock durability determined by freeze-thaw test the high water absorption was set in Slovakia as exclusion criterion for use of rocks and stones in building industry for many years. Only after 1989 was the absorption accepted as merely informational value. The reason of the change was not the understanding of the relationship between the absorption and rock deterioration, but more or less good service record of some high porous rocks used in constructions exposed to severe weather conditions and proving lack of relationship between rock freeze-thaw resistivity and water absorption proved by Čabalová [7], [8]. One for all examples of good service record of some high porous rocks used in constructions exposed to severe weather condition is Rotunda building located on Mount Chopok in the Nízke Tatra Mountains at $2000 \mathrm{~m}$ a.s.l. built over 60 years ago (Fig. 1). The building is made of rhyolite with high porosity, granite with low porosity and concrete and brick. While rhyolite and granite look almost the same as
60 years ago, the concrete and bricks are completely disintegrated.

Results of the recent worldwide researche suggest that understanding the resistivity of rock against rock deterioration is hidden not in the total or effective porosity but in the structure of rock pores (porosity, location of pores, pore size distribution, volume of pores, interior surface of pores) in relation to thermodynamic properties of water present in rock pores and tensile strength of rocks and rock minerals [15]-[17], [35], [36]. Also this article presents some results of research on rock deterioration estimation in relation to rock pore structure. However, the rock pore structure is not measured directly by tests like mercury intrusion porosimetry (MIP) or BET method [11], [31] for specific surface area (SSA). The pore structure in this research was identified by very simple tests like water adsorption and water absorption [22].

\section{CHARACTERISTICS OF THE ROCK PORE STRUCTURE}

The basic rock pore characteristics are defined by the volume of pores (porosity), size of pores (diameter), specific interior surface, pore size distribution, shape, geometry and interconnection of pores.

\subsection{POROSITY}

The porosity is usually defined as the ratio between the volume of pores to total volume of rock [3]. Total porosity and open (effective) porosity are distinguished [12], [25]. The total porosity includes all pores in a rock, the open porosity only mutually interconnected pores, i.e., pores transmitting pore water. The difference between total and open po-

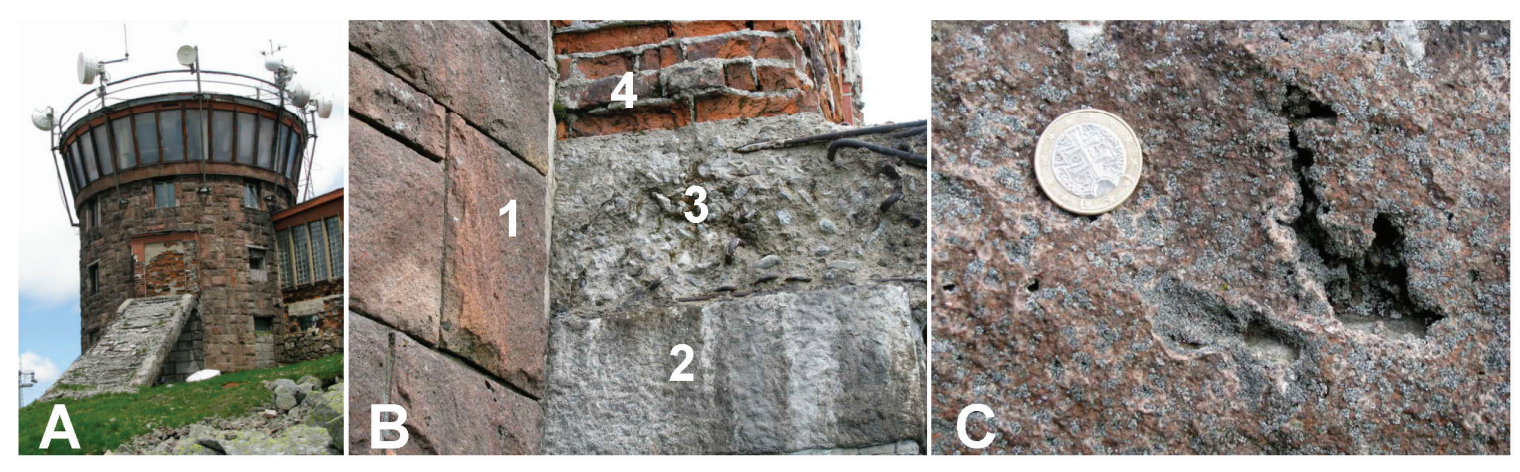

Fig. 1. (A) Rotunda building located on Mount Chopok in the Nízke Tatra Mountains in Slovakia, built over 60 years ago; (B) the building is made of rhyolite with high porosity (1), granite with low porosity (2) and concrete (3) and bricks (4);

(C) rhyolite contains large pores and cavities 
rosity varies; it depends upon rock type and its postgenetic development [33].

\subsection{PORE SIZE}

Authors of many papers concerning the pore size are using relative and vague expressions, like small pore, larger pore, micropore, macropore, etc. Many times the terms are not defined and the reader is not sure about the real size of the pore. In Fig. 2, there is an overview of pore size classification according to different authors, as published in their works. From the first sight it is clear that pore size classification and terminology is not uniform, which is probably due to the various purposes of the pore size classification (migration of water in pores, adsorption of chemical compounds, excavation of crude oil from rock environment, methodology of pore size measurement, etc.). For the purpose of evaluating the influence of rock pore structure and pore water on rock deterioration most suitable appears to be classification of pore size distribution based on the behavior of water in rock pores described by Kelvin's equation:

$$
\ln \frac{p}{p_{o}}=2 \frac{\gamma}{r} \frac{M}{R T \rho_{v}}
$$

where

$p, p_{0}$ - vapour pressure over adsorbed water and bulk water, respectively $[\mathrm{Pa}]$,

$p / p_{0}$ - relative vapour pressure (relative humidity),

$\gamma$ - surface tension of water $\left[\mathrm{N} \cdot \mathrm{m}^{-1}\right]$, at absolute temperature $T[\mathrm{~K}]$,

$r$ - capillary radius $[\mathrm{m}]$,

$M$ - molecular weight of liquid, $\left[\mathrm{kg} \cdot \mathrm{mol}^{-1}\right]$,

$R$ - the gas constant $\left[\mathrm{J} \cdot \mathrm{K}^{-1} \cdot \mathrm{mol}^{-1}\right]$,

$\rho_{v}$ - density of liquid, $\left[\mathrm{kg} \cdot \mathrm{m}^{-3}\right]$.

A model of condensation of water vapors on the walls of pores with sizes from $10 \mathrm{~nm}$ to $0.1 \mathrm{~mm}$ based
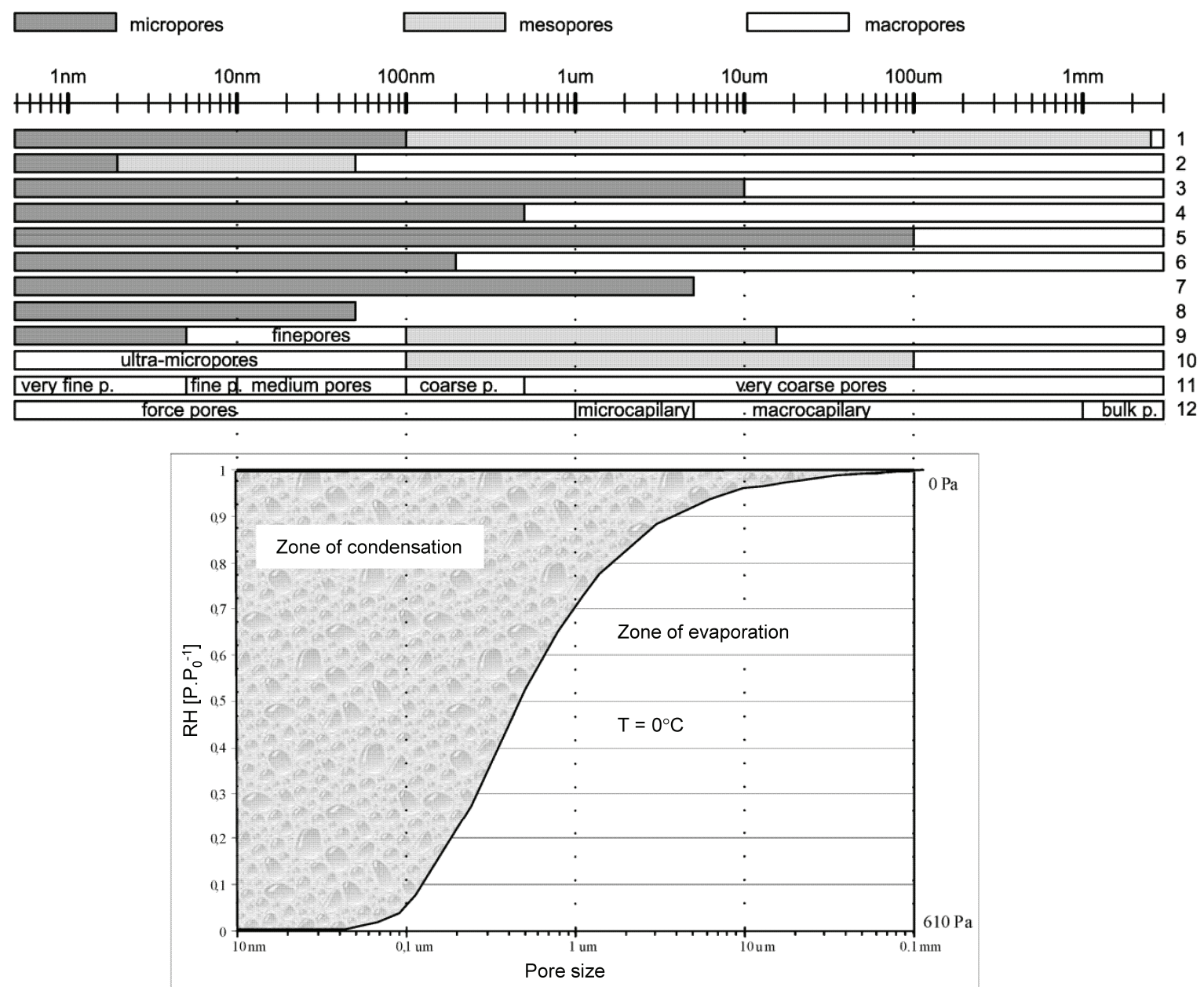

Fig. 2. Classification of pore size according to different authors related to the model of condensation of water in pores according to Kelvin's equation at a temperature of $0{ }^{\circ} \mathrm{C} .\left(P, P_{0}\right.$-vapor pressure over adsorbed water and bulk water, respectively, $P \cdot P_{0}^{-1}, \mathrm{RH}-$ relative humidity),

1 - Benaventure et al. [4], [5], 2 - Fischer [13], 3 - Hiltmann et al. [14], 4 - Struhárová et al. [34], 5-Struhárová et al. [34], 6 - Dejian et al. [9], 7 - Benaventure et al. [6], 8 - Wardeh [36], 9 - Lach et al. [23], 10 - Acadorcjan [1], 11 - Kate et al. [22], 12 - Hudec [16] 
on Kelvin's equation at a temperature of $0{ }^{\circ} \mathrm{C}$ is given in the graph of Fig. 2. The model divides the pores according to their size into three intervals: pores with diameter less than $0.05 \mu \mathrm{m}$ (or $50 \mathrm{~nm}$ ), pores within interval from $0.05 \mu \mathrm{m}$ up to $100 \mu \mathrm{m}$ and pores with size greater than $100 \mu \mathrm{m}$ (or $0.1 \mathrm{~mm}$ ). Such classification of pore sizes is quite consistent with the one by Acadorcjan [1]:

- the smallest pores we can call nanopores $(<50 \mathrm{~nm})$. They can contain only adsorbed water without respect to relative humidity $(\mathrm{RH})$ because even at low RH they are filled with adsorbed water (condensed water),

- middle interval of the pore size (Fig. 2) we can call micropores or microcapillaries $(0.05-100 \mu \mathrm{m})$. These pores are filled with adsorbed water in relation to $\mathrm{RH}$ of the environment. Most of the pores of this pore size interval can be filled with adsorbed water at high RH of the environment,

- the largest pores are called macropores or macrocapillaries (from $0.1 \mathrm{~mm}$ up to ca $1 \mathrm{~mm}$ ), which according to Fig. 2, are never entirely filled with adsorbed water. The macropores contain closed capillary air thus cannot be fully saturated with water unless vacuum saturation is applied [10], [20]. The water freezes in them at temperatures close to $0{ }^{\circ} \mathrm{C}$.

- In addition to the three intervals of pore sizes we have also pores larger than $1 \mathrm{~mm}$ which can be called bulk pores or cavities and contain gravitational water (water free of capillary forces). The water in bulk pores freezes at temperatures close to $0{ }^{\circ} \mathrm{C}$.

\subsection{PORE SIZE DISTRIBUTION}

Pore size distribution is an important part of the rock pore structure. It controls a mutual relationship between nano, micro, macro and bulk pores of the total porosity of the rocks (Fig. 3). If rock has high porosity with prevailing macro and bulk pores, then the rock has small interior surface of pores (specific surface area). On the other hand, rock with high porosity in which nano and micro pores are dominant, has high specific surface area. The specific surface area of pores may be very large, up to several dozen thousands $\mathrm{cm}^{2}$ per $\mathrm{cm}^{3}$ and is controlled by the pore size [18]. The smaller the pores in the rock, the larger the specific surface area. The size of specific surface area is very important for the amount of water the rock can adsorb, thus by the amount of adsorbed water the apparent surface area of pores can be indirectly measured, which is consistent with results by Rigbey [30] and Kate et al. [22].

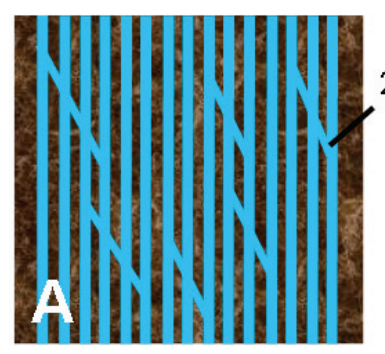

$\mathrm{n}_{1}$

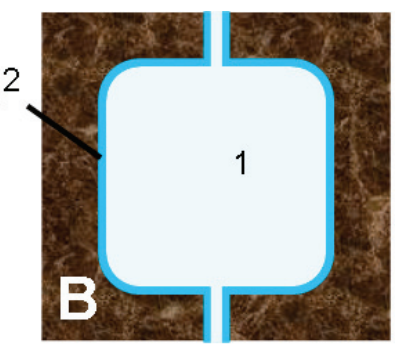

$\mathrm{n}_{2}$
Fig. 3. Illustration of two rocks with the same porosity $n\left(n_{1}=n_{2}\right)$ : rock (A) contains micropores only filled with adsorbed water; rock (B) has bulk pore and macropores only filled with bulk water; (1) bulk water, (2) adsorbed water

\subsection{DISTRIBUTION, SHAPE AND INTERCONNECTION OF PORES}

Important part of pore structure is also distribution of pores in the rock body, their shape and mutual interconnection. These three pore characteristics have direct impact on degree of saturation of the rock which is important for rock deterioration. For example, if the macropore or bulk pore is surrounded by micropores or mesopores only, then due to capillary suction under natural conditions the bulk pore will remain occupied with air bubble. This phenomenon is called ink-bottle effect and air entrapment.

\section{PORE WATER}

Water present in rock pores (pore water) is also called absorbed water. It consists of bulk water and adsorbed water. Bulk water is water present in macro and bulk pores and its thermodynamic properties are similar to water outside of pores (especially freezing point and vapor pressure). Adsorbed water is the result of physical adsorption of water molecules on the surface of micro and nanopores. It is caused by van der Waal's forces between the water molecules and the solid surface [24]. The adsorption is reversible, which means the existence of an adsorption-desorption equilibrium controlled by temperature and pressure (relative humidity) [32], no chemical reactions take place. The adsorbed water does not create a monolayer of water molecules adsorbed on a pore surface but it may advance into a multilayer [2], thus micropores can be completely filled with adsorbed water at high relative humidity. The adsorbed water has different thermodynamic properties than bulk 
water (lower freezing point and lower vapor pressure). This difference is the reason of intensive osmotic pressure and osmotic movement of water in pores when thermodynamic equilibrium is disturbed by temperature changes (below and above $0{ }^{\circ} \mathrm{C}$ ).

\section{ROCK DETERIORATION ON FREEZE-THAW CYCLES}

The most destructive breakup of rocks takes place at cyclic freezing and thawing of water in rock pores. However, the question is: what is the real cause of such rock breakup? The first mechanism of deterioration of porous media on freezing was described by Powers [28]. He suggested the hydraulic pressure theory. According to this theory, high hydraulic pressure is generated by $9 \%$ volume increase of freezing water in closed pore space. Darcy's law of water flow through porous media was used to describe this pressure. Verbeck and Landgren [35] defined this pressure as a function of porosity, degree of saturation, permeability and size of aggregate particles. The succession of the hydraulic pressure is shown in Fig. 4. Part 1 represents macropore saturated with water. If the temperature decreases below freezing point, then part of the water freezes and increases its volume by $9 \%$. The ice creates pressure acting toward the pore walls and unfrozen water in neighboring pores which is pushed in the pore by ice like hydraulic fluid by piston in the cylinder, which generates hydraulic pressure. If the extra volume of the ice and unfrozen water pushed by the ice has an escape space (pore filled with air, for instance), then the pressure is relaxed and the pore walls remain undamaged (Fig. 4, part 2). However, if the additional ice volume has no escape space, then the pore walls can get damaged (part 3, Fig. 4).

Because the theory of hydraulic pressure did not explain all observations, Powers continued with research and in 1975 introduced a theory of osmotic pressure [29]. The theory is based on different thermodynamic properties of bulk water, adsorbed water and ice. According to this theory at temperatures
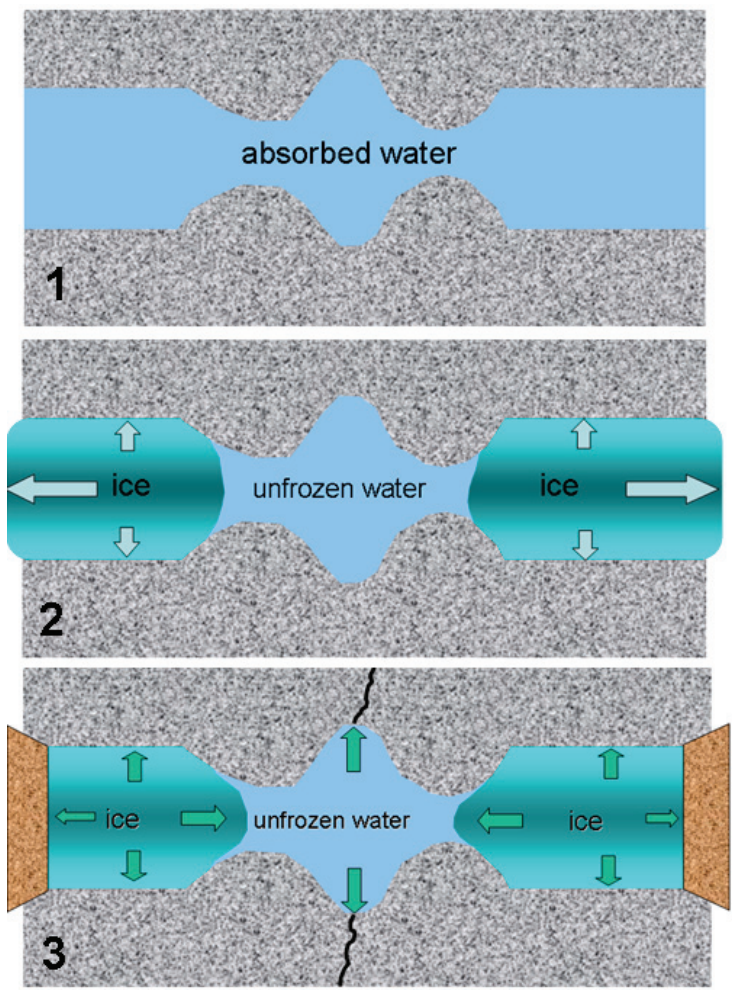

Fig. 4. Diagram of rock pore deterioration by hydraulic pressure: 1 - bulk water in the macropore, 2 - water frozen in the open macropore, 3 - closed macropore damaged by frozen water

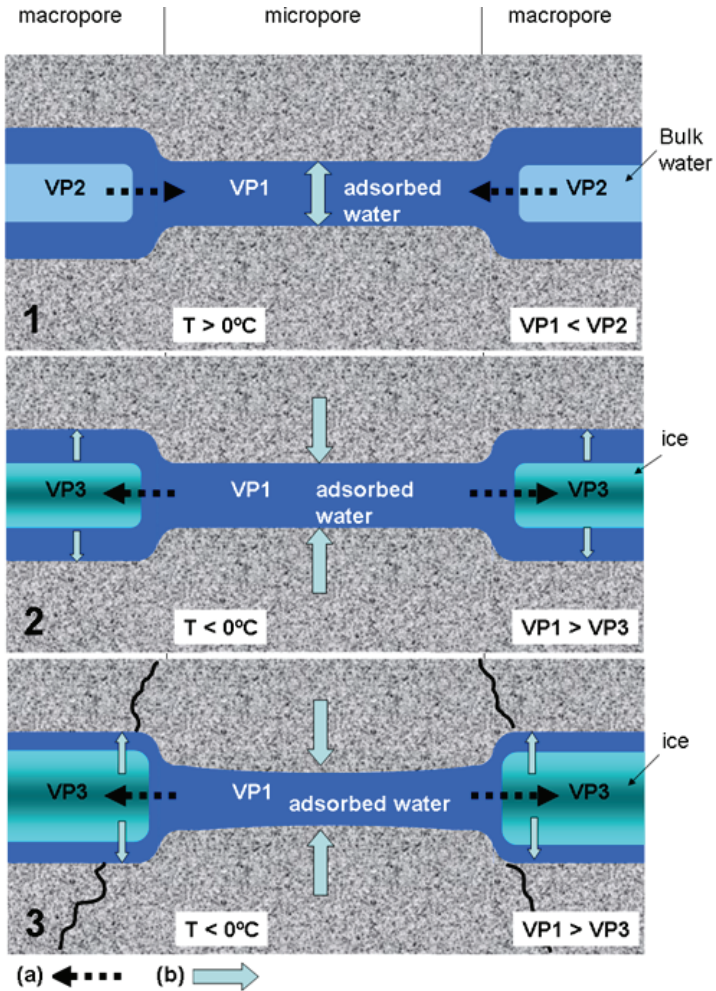

Fig. 5. Diagram of rock pore deterioration by osmotic pressure. VP1, VP2, VP3 - vapor pressure of adsorbed water, bulk water and ice, respectively: 1 - Osmotic flow of bulk water from macropores to micropores at temperature $T>0{ }^{\circ} \mathrm{C}, 2$ - osmotic flow of adsorbed water from micropores to macropores with ice at $T<0{ }^{\circ} \mathrm{C}, 3$ ) rock damaged by osmotic pressure;

(a) Direction of water molecule movement, (b) direction of pressure 
above freezing point, the bulk water in macro and bulk pores has higher free energy (vapor pressure) than adsorbed water in nano and micropores, which gives to the molecules of the bulk water the potential to move towards nano and micropores (principle of osmosis), generating pressure on pore walls in the nano and micropores. The movement of water molecules continues until the pressure on pore walls equals to osmotic pressure and the thermodynamic balance is set (Fig. 5, part 1). If the temperature decreases below freezing point of water, the bulk water freezes, but the adsorbed water does not because of strong interactions between water molecules and pore walls. This results in disruption of the thermodynamic balance. Now, the ice has lower free energy than adsorbed water, thus the molecules of water adsorbed in nano and micropores start to move towards ice in macro and bulk pores where it freezes and increases the volume of ice. As a result of this movement, the pressure in nano and micropores is decreasing and the pressure in macro and bulk pores is increasing (Fig. 5, part 2). If the pressure exceeds ultimate tensile strength of a rock or rock minerals, then the pore walls are broken (Fig. 5, part 3), especially if the process of osmotic movement of pore water is repeated due to repeating of freeze-thaw cycles.

The breakup of pore walls can occurs only if the ice has no space to expand, like air filled pores. If the degree of saturation is greater than $90 \%$, then the breakup can occur. It means that the degree of saturation is crucial for freeze-thaw rock deterioration.

Kaneuji et al. [21] presents the results of tests in which they focused on the impact of pore size on behavior of rocks exposed to cycles of freezethawing. The results indicated that in the rock aggregate with an equal volume of pores the less durable is the one which contained more micropores. Hudec [17], [19] had similar results in his research. Based on his observations Hudec expressed doubts whether the ice formation is the main mechanism of rock deterioration. As an argument he presents the fact that because of its thermodynamic properties the water in nano and micropores cannot freeze at temperatures near $0{ }^{\circ} \mathrm{C}$ and just rocks with high content of nano and micropores have the highest weight lost on freeze-thaw tests. He concluded that the amount of adsorbed water in relation to bulk water decides whether the mechanism of rock deterioration is caused mainly by osmotic forces or by water freezing and subsequent hydraulic forces. The ratio between adsorbed and bulk water is a function of the pore size. If the rock contains mainly micropores then osmotic processes are dominant, if macropores are dominant then hydraulic forces are prevailing, provided that all the pores are completely saturated with water.

\section{METHODS OF THE RESEARCH AND VARIABLES}

In the research, series of tests have been performed. The tests included also tests on rock durability (freeze-thaw loss), identification of amount of frozen water (calorimetric test) and tests on content of water in pores, which are at the same time also indirect identification of some characteristics of rock pore structure: water saturation by boiling (apparent effective porosity), water adsorption and absorption (apparent interior surface of pores, size of pores and pore size distribution). The research was performed on 88 samples, most of them were limestones and dolostones, and also some sandstones, shales and granitic rocks were included. A detailed description of the tests and test rock samples is given in the work by Ondrášik [26], [27]. The following variables were obtained by the tests:

Absorbed water - observed weight of absorbed water expressed as weight percent of dry rock. It was tested by 24 hour water saturation at room temperature.

Adsorbed water - weight of water adsorbed into rock pores from air moisture expressed as weight percent of total weight of dry rock. It was tested by 72 hour water adsorption at room temperature and $98 \%$ relative humidity.

Adsorbed water portion is weight of adsorbed water expressed as weight percent of weight of absorbed water.

Apparent effective porosity is weight of water saturated by 4 hour boiling and 20 hour cooling and saturation expressed as weight percent of dry rock.

Bulk water is a weight of bulk water present in the pores of the samples tested. It is calculated by subtracting adsorbed water from absorbed water and expressed as weight percent of dry weight of samples.

Observed frozen water is an amount of frozen water calculated from heat released from freezing pore water (calorimetric measurements). It is expressed as weight percent of dry rock. The lowest temperature on freezing was $-20{ }^{\circ} \mathrm{C}$, but the only freezing that occurred was at a temperature of about $-3 \mathrm{C}$. 
Freeze-thaw loss is weight loss of rock aggregates after 25 freeze/thaw cycles. The loss is expressed as weight percent of dry weight of samples prior to testing.

\section{TEST RESULTS}

The test results crucial for this article can be briefly summarized in the six graphs presented in Figs. 6-11. Graphs in Figs. 6 and 7 show relationship of absorption versus freeze-thaw loss and relationship of adsorption versus freeze-thaw loss, respectively. As can be seen, there are no relationships or only small ones in the case of content of adsorbed water and freeze-thaw loss. The correlation coefficient $R$ is 0.51 .

Graphs in Figs. 8 and 9 are the same as in Figs. 6 and 7 , but this time the samples are divided into two groups. The first group assigned with $\mathrm{F}$ and denoted by empty circles represents the samples in which the

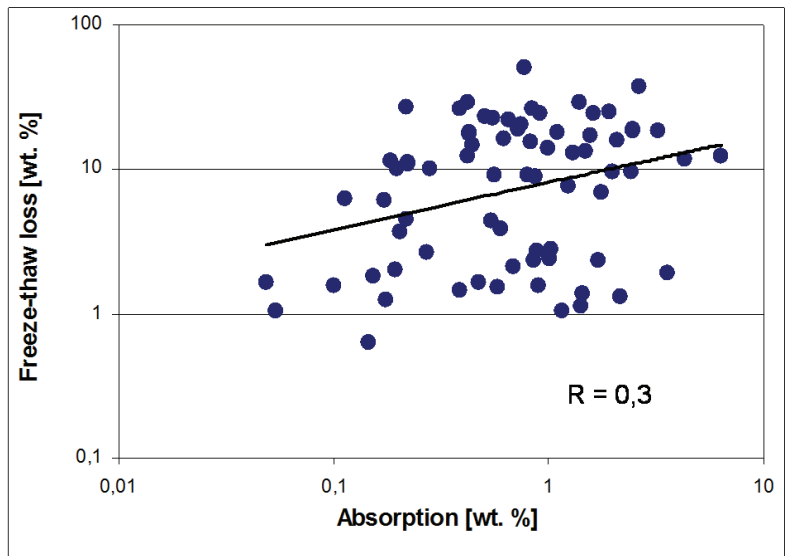

Fig. 6. Relationship between absorption and freeze-thaw loss

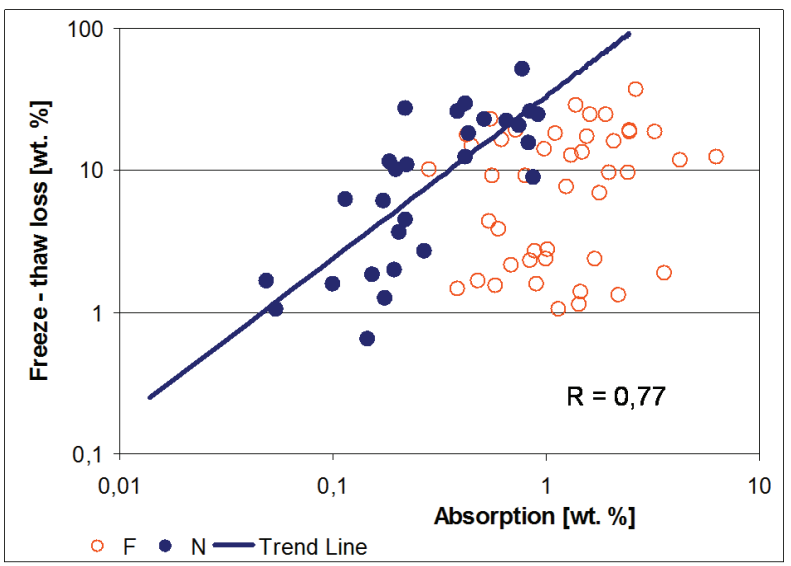

Fig. 8. Relationship between absorption and freeze-thaw loss with samples classified into groups $\mathrm{F}$ and $\mathrm{N}$ pore water had frozen after the temperature dropped below the freezing point of water. The second group assigned with $\mathrm{N}$ and denoted by full circles represents the samples in which the pore water did not freeze after the temperature had dropped below the freezing point. Samples with frozen water in pores (group F) are arranged on both graphs in clouds of samples without any relationship. However in the case of samples without frozen water (group $\mathrm{N}$ ) the graph shows significant direct correlation between absorption and freeze-thaw loss (Fig. 8) and between adsorption and freeze-thaw loss (Fig. 9). The correlation coefficients $R$ are 0.77 and 0.81 , respectively.

The last graph (Fig. 10) shows relationship of adsorption with apparent effective porosity of the test rock samples. On the graph there are the same groups of rock samples as in graphs of Figs. 8 and 9. The samples from group $F$ are scattered in cloud without any correlation. On the contrary, the correlation of the samples from group $\mathrm{N}$ is significantly strong $(R=0.85)$. On the graph there is also so called null line which represents trend

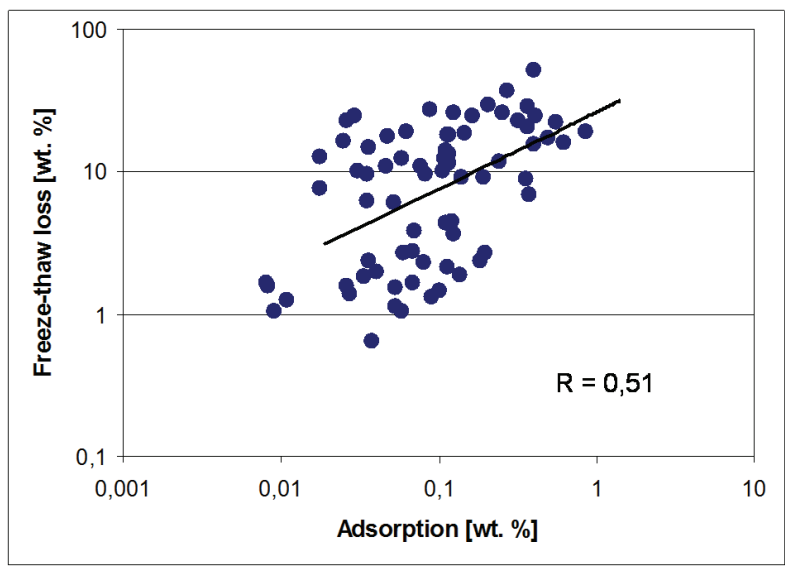

Fig. 7. Relationship between adsorption and freeze-thaw loss

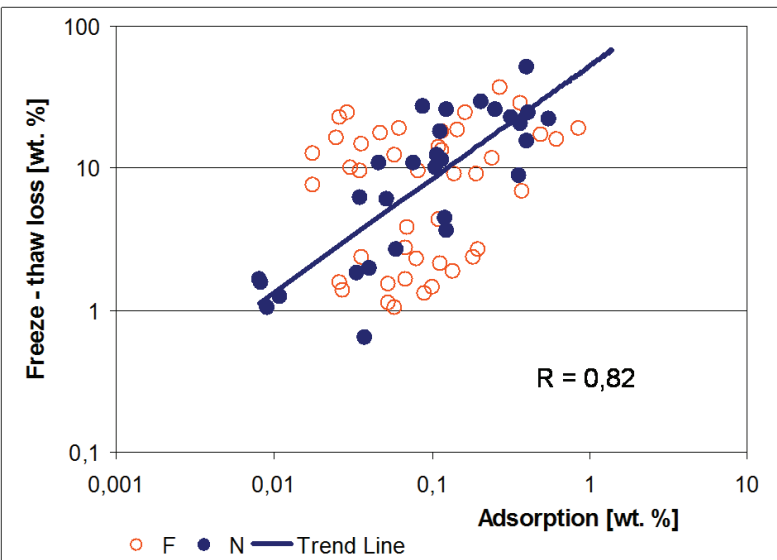

Fig. 9. Relationship between adsorption and freeze-thaw loss with samples classified into groups $\mathrm{F}$ and $\mathrm{N}$ 


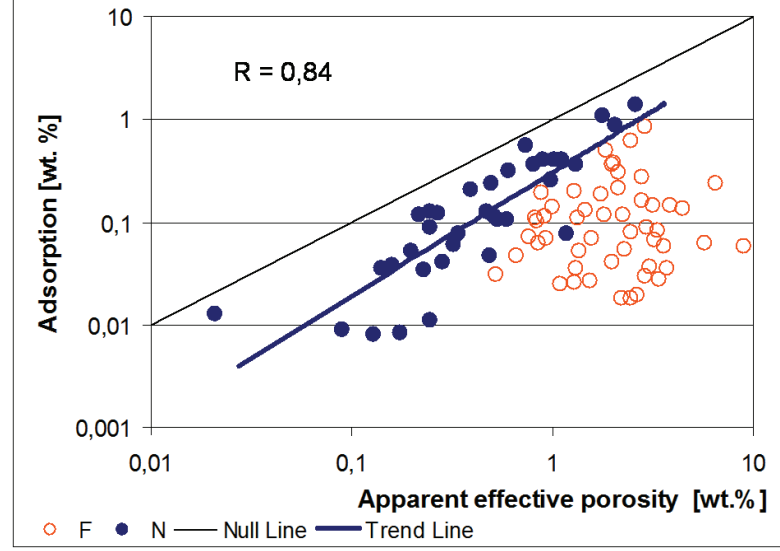

Fig. 10. Relationship between apparent effective porosity and adsorbed water

line of theoretical correlation of variables, which have the same values on both $x$ and $y$ axis of the graph. The closer the real samples are located to the null line, the greater the portion of the pore space in the rock sample is occupied with adsorbed water (the more micropores are present in the sample). It is apparent that rock samples from group $\mathrm{N}$ are located closer to the null line than rock samples from group F. It means that at certain portion of adsorbed water that occupies the pore space the water in pores does not freeze. This portion in relation to apparent porosity is shown in the graph of Fig. 11. As can be seen, there is quite sharp and straight border between groups $\mathrm{F}$ and $\mathrm{N}$ and can be outlined by straight line A. The slope of the line suggests that the portion of the adsorbed water is different for different apparent effective porosity. For example, at the porosity less than $0.3 \%$ the water in pores does not freeze, if it contains more than $5 \%$ of adsorbed water. On the other hand, according to this graph, if the porosity is $3 \%$, then the content of adsorbed water should be more than $50 \%$ of the water present in the rock pores.

\section{DISCUSSION}

As we have mentioned in the introduction, by 1989 in Slovakia the water absorption was one of the crucial limiting criteria for acceptance or rejection of rocks for building industry. However, comparison of the results of tests on water adsorption and freezethaw loss (Fig. 6) shows no correlation, as was expected. Some authors [15] presented good relationship between the content of adsorbed water and freezethaw loss, but the same correlation performed on our data did not give significant result (Fig. 7). Only low

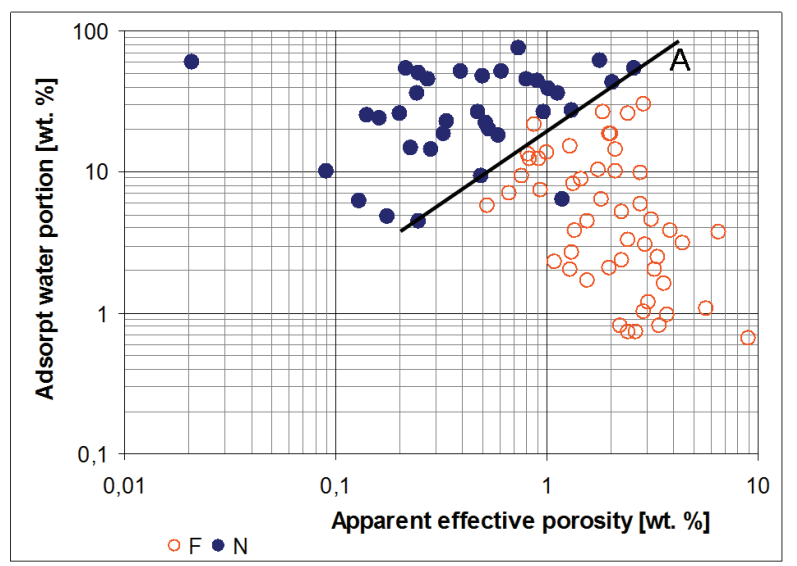

Fig. 11. Relationship between apparent effective porosity and adsorbed water portion

correlation with $R=0.51$. A high degree of saturation is considered to be important in the case of frost damage, but a simple comparison of the degree of saturation with freeze-thaw loss showed no correlation. In our research, data on length change of rock sample after freezing of pore water and data on amount of frozen water in pores were also available, but correlation of these data with freeze-thaw loss gave no correlation either.

After we had applied the results from the calorimetric measurements which divided the samples into two groups, $\mathrm{F}$ and $\mathrm{N}$, the data on the graphs start to make sense. Distinction between samples with freezing water $(\mathrm{F})$ and without freezing water in pores $(\mathrm{N})$ is significant (Figs. 8 and 9). On both graphs the distribution of samples from group $\mathrm{F}$ still did not give any correlations. Distribution of samples from group $\mathrm{N}$ shows significant correlation of absorbed water and adsorbed water with freeze-thaw loss $(R=0.77$ and $R=0.81$, respectively). The correlations mean that in tested rock samples in which water have not frozen the freeze-thaw loss is increasing with increasing content of absorbed water or adsorbed water.

The two correlations in graphs of Figs. 8 and 9 are similar. The similarity is because for the samples from group $\mathrm{N}$ there is also a high direct correlation of content of absorbed water with the content of adsorbed water $(R=0.85)$, which is well documented in graph of Fig. 10. Therefore, it can be assumed that if most or critical portion of water in pores is adsorbed water, then also the absorbed water (which includes adsorbed water) has high correlation with freeze-thaw loss (as illustrated in Fig. 8), or we can say, the adsorbed water in pores makes the correlation with freeze-thaw loss, not the absorbed water itself. After this analysis we can again interpret the meaning of correlations in graphs of Figs. 8 and 9 as: the correlations mean that 
in the rock samples tested in which water does not freeze the freeze-thaw loss is increasing with increasing content of adsorbed water.

The last statement is very important, because now we can distinguish between two rock groups. The first group of rocks contains the critical amount or more of adsorbed water which prevents freezing of water in pores. This group is represented by samples from group $\mathrm{N}$ the deterioration of which by freeze-thaw cycles is dominantly controlled by the presence of adsorbed water and can be predicted thanks to the existence of correlation of water adsorption with freeze-thaw loss. Since the water does not freeze in these rocks, their deterioration is caused by osmosis, as described by Powers [29]. The second group of rocks does not contain a critical amount of adsorbed water, their pore water freezes and is represented by samples from group F. Their deterioration is caused not only by osmosis, but also by some other processes and influences, such as hydraulic pressure, permeability, grain size, rock and mineral tensile strength, degree of saturation, etc. Such deterioration is not yet well understood to be predictable by a simple correlation.

We do not have to make calorimetric measurements to identify to which group the test rocks belong. For division of the rocks to the two groups we can determine the critical portion of adsorbed water present in pores from the graph in Fig. 11, where apparent effective porosity is related to adsorbed water expressed as portion of absorbed water. On the graph, there exists a distinct border between samples from groups $\mathrm{F}$ and $\mathrm{N}$, which is represented by the line " $\mathrm{A}$ ". Since the line "A" in the graph of Fig. 11 divided the graph in two parts, we can denote the part above the line with rocks from group $\mathrm{N}$ as domain of osmotic forces deteriorating rocks and the part below the line "A" with rocks from group $\mathrm{F}$ as domain of osmotic and hydraulic forces deteriorating rocks influenced also by pressure, permeability, grain size, rock and mineral tensile strength, degree of saturation and other factors.

The observations of the research are based on the content of absorbed, adsorbed and bulk water in the pores. Since the amount and portions of these waters in pores are a function of pore volume, size and size distribution (ratio of nano, micro, macro and bulk pores), then we can conclude that the deterioration of rocks with critical content of adsorbed water is strongly or solely related to pore structure and content of adsorbed water. In the case of rocks without dominance of adsorbed water the relation to pore structure is not clear yet and must be studied further. The results are obtained mostly on limestone and dolostone rock samples. Other rock types must be studied in detail also.

\section{CONCLUSIONS}

Based on the test results and discussion we can make the following conclusions:

- Two groups of rocks were recognized with respect to freezing of water in pores. In the first group (N) the pore water does not freeze even when the temperature decreases to $-20{ }^{\circ} \mathrm{C}$, in the second group (F) the water freezes.

- The rocks from group $\mathrm{N}$ contain significant (critical) portion of adsorbed water in pores which prevents freezing of the pore water.

- The critical portion of adsorbed water is not constant, but it depends upon effective porosity.

- The rock deterioration of group $\mathrm{N}$ depends upon the content of adsorbed water, with increasing amount of adsorbed water in pores the rock durability is decreasing.

- The reason of deterioration of rocks from group $\mathrm{N}$ is thermodynamic processes related to osmosis, as described by Powers [29].

- The rock deterioration of group $\mathrm{F}$ is caused not only by osmosis, but also by some other processes and influences, such as hydraulic pressure, permeability, grain size, rock and mineral tensile strength, degree of saturation, etc.

- Since the content of absorbed water and ratio between adsorbed and bulk water (of which absorbed water consists) are controlled by the porosity and pore structure, it can be concluded that the deterioration of rocks is related to the rock pore structure and we can say that rock pore structure is the main reason of rock deterioration.

The obtained results of the research are promising for cheap, simple and quick durability estimation of natural porous construction materials used in historical buildings and considered to be used for constructions or restoration. Instead of the freeze-thaw tests lasting three or more weeks we can make tests lasting maximum three days which can then be used for rock durability estimation.

\section{REFERENCES}

[1] Acadorcjan Z.A., Prirodnyje kamennyje materialy Armenii, Izdatel'stvo literatury po stroitel'stvu, Moscow, 1967, 240.

[2] Adamson A.W., Physical chemistry of surfaces, A WileyInterscience Publication, New York, 1982, 777. 
[3] BATES R.L., JACKSON J.A., Dictionary of geological terms, Third Edition, The American Geological Institute, New York, 1984, 571.

[4] Benaventure D., Garcia Del Cura M.A., Ordonez S., Thermodynamic modelling of changes induced by salt pressure crystallisation in porous media of stone, Journal of Crystal Growth, 1999, 204, 168-178.

[5] Benaventure D., Garcia Del Cura M.A., Bernadeu S., ORDONEZ S., Quantification of salt weathering in porous stones using an experimental continuous partial immersion method, Engineering Geology, 2001, 59, 313-325.

[6] Benaventure D., Garcia Del Cura M.A., Garcia-Guinead J., SAnchez-Moral S., Ordonez S., Role of pore structure in salt crystallisation in unsaturated porous stone, Journal of Crystal Growth, 2004, 260, 532-544.

[7] ČABALOVÁ D., Štúdium nasiakavosti vulkanických hornín Slovenska z hl'adiska možnosti ich využitia pre ušl'achtilú a hrubú kamenársku výrobu, Geologický Průzkum, 1988, Vol. 30, No. 2, 40-44.

[8] ČABALOVÁ D., Výsledky štúdia pórovej štruktúry vulkanických hornin Slovenska, Acta Polytechnica, Práce ČVÚT, Prague, 1989, 41-47.

[9] Dejian L., Guilian W., Liqiang H., Peiyu L., Manchao H., Guoxing Y., QIMIN T., CHeng C., Analysis of microscopic pore structures of rocks before and after water absorption, Mining Science and Technology, (China), 2011, 21, 287293.

[10] DunN J.R., HudEC P.P., Frost and sorption effects in argillaceous rocks. Frost action in soils, Highway research record, No. 393, National Research Council, Washington, D.C., 1972, 65-78.

[11] FAGERLund G., Determination of specific surface by the BET method, Materials and Constructions, 1973, Vol. 6, 239-144.

[12] Fetter C.W., Applied Hydrogeology, Second Edition, Macmillan Collage Publishing Company, 1994, 77-128.

[13] FISCHER C., GAUPP R., Multi-scale rock surface area quantification - a systematic method to evaluate the reactive surface area of rocks, Chemie der Erde, 2004, 64, 241-256.

[14] Hiltmann W., Stribrny B., Tonmineralogie und Bodenphysik, Handbuch zur Erkundung des Untergrundes von Deponien und Altlasten, Springer, Berlin, 1998, Vol. 5, 297.

[15] HudEC P.P., Durability of carbonate rocks as function of their thermal expansion, water sorption, and mineralogy, ASTM Tech. Pub., 1980, 691, 497-508.

[16] Hudec P.P., Deterioration of aggregates. The underlying causes, Katharine and Bryant Mather International Conference on Concrete Durability, American Concrete Institution, Detroit, Michigan, 1987, 1325-1342

[17] HUDEC P.P., Freezing or osmosis as deterioration mechanism of concrete and aggregate? Low temperature effects on concrete proceedings, Second Canadian/Japan Workshop, Ottawa, Ontario, 1991, 1-7.

[18] Hudec P.P., Aggregate and concrete durability as controlled by water and cation adsorption and osmosis. Proceeding of Del seminario international sobre technologia del concreto, Concrete Durability, Monterrey, Mexico 1993, 32-52.
[19] HudEC P.P., Vlastnosti hornín a fyzikálne procesy pri urýchlenom zvetrávaní, Zborník z 2. seminára Výroba Kameniva *98 so zahraničnou účast’ou, Stará Lesná, 1998, 35-42.

[20] Hudec P.P., SitAR N., Effect of sorption on carbonate rock expansion, Canadian Geotechnical Journal, 1975, Vol. 12, No. 2, 179-186.

[21] Kaneuji M., Winslow D.N., Dolch W.L., The relationship between an aggregate pore size distribution and its freezethaw durability in concrete, Cement and concrete Research, 1980, 10 (3), 433-441.

[22] Kate J.M., GoKhale C.S., A simple method to estimate complete pore size distribution of rocks, Engineering Geology, 2006, 84, 48-69.

[23] LACH V., DAŇKOVÁ M., Mikrostruktura stavebních látek, ES VUT, Brno, 1987, 170.

[24] Mantell C.L., Adsorption, McGraw-Hill Book Company, Inc., New York, 1951, 634.

[25] North F.K., Petroleum Geology, Allen \& Unwin, Boston, USA, 1985, 115-126.

[26] ONDRÁŠIK M., Vplyv štruktúry pórov a vlastností v nich uzavretej vody na rozpad hornin, $\mathrm{PhD}$ Thesis, Department of Engineering Geology, PriF UK, Bratislava, 2004.

[27] ONDRÁŠIK M., Vplyv štruktúry pórov a vlastností v nich uzavretej vody na rozpad hornín, Geologické Práce, Bratislava 2006, No. 112, ŠGÚDŠ, 79-95.

[28] POWERS T.C., The air requirements of frost-resistant concrete, Proceedings of the Highway Research Board, 1949, 29, 184-211.

[29] POWERS T.C., Freezing effect in concrete. Durability of concrete, ACI SP47, American Concrete Institute, Detroit, Michigan, 1975, 1-11.

[30] RigBey S.J., The effect of sorbed water on expansivity and durability of rock, Master thesis, University of Windsor, 1980, 169.

[31] Rouquerol J., Avnir D., Fairbridge C.W., Everett D.H., HAynes J.H., Pernicone N., RAMSAY J.D.F., Sing K.S.W., UNGER K.K., Recommendations for the characterization of porous solids, Pure and Applied Chemistry, 1994, 66, 1739-1758.

[32] RuthVen D.M., Principles of adsorption and adsorption processes, A Wiley-Interscience Publication, New York, 1984, 464.

[33] Sigurdsson O., Gumundsson A., Frileifsson O., FranZSON S., StEFANSSON V., Database on igneous rock properties in Icelandic geothermal systems, status and unexpected results, Proceedings of World Geothermal Congress 2000, Kyushu-Tohoku, Japan, 2000, 2881-2886.

[34] StruhÁrová A., Rouseková I., Porous structure of cellular concrete and its impact on selected physical-mechanical properties of cellular concrete, Slovak Journal of Civil Engineering, STU Bratislava, 2007, Vol. 2, 35-43.

[35] VERBECK G., LANDGREN R., Influence of physical characteristics of aggregates on frost resistance of concrete, Proceedings of the American Society for Testing and Materials, 1960, 1063-1079.

[36] Wardeh G., Perrin B., Freezing-thawing phenomena in fired clay materials and consequences on their durability, Construction and Building Materials, 2008, Vol. 22, 820-828. 